\title{
DIÁLOGOS ENTRE MÚSICA E LITERATURA NA AMAZÔNIA: RELATOS DE UMA CERTA MPB
}

\author{
DIALOGUES AMONG MUSIC AND LITERATURE IN THE \\ AMAZON: DESCRIPTIONS OF A CERTAIN MPB
}

\section{Josiclei de Souza Santos ${ }^{1}$}

Resumo: A MPB, embora inclua uma produção diversa, possui um elemento que a unifica, ao menos em sua maioria: o trabalho com a palavra poética. Nesse sentido, o presente trabalho busca fazer um estudo da MPB amazônica enquanto uma poesia cantada que, embora com elementos comuns ao cânone nacional da MPB, possui aspectos diferenciais, que fazem com que seja preciso se criar uma outra narrativa sobre a mesma. Sem desmerecer a narrativa de invenção da MPB, de caráter urbano, no dizer de Wisnik (2008), e iniciada com Vinícius de Moraes e os bossa-novistas, no dizer de Tatit (2004), o estudo da poesia cantada amazônica mostra que é preciso ter-se cuidado com as homogeneizações, já que, por exemplo, o urbano na Amazônia é diferente do urbano sudestino, havendo a interpenetração do elemento citadino com a floresta. No que diz respeito à aproximação entre música e poesia, sem negar a importância de Vinícius de Moraes na década de 50, há desde a década de 30 o trabalho de Waldemar Henrique com a palavra poética, gerando uma tradição poética cantada que, iniciada pelo maestro, passa por Ruy e Paulo André Barata, Walter Freitas, chegando até a contemporaneidade.

Palavras-chave: Poesia cantada. MPB. Amazônia.

\begin{abstract}
MPB, although it includes a diverse production, it owns an element which unifies it, at least in the majority: the work with the poetic word. Thus, the present work seeks to make a study of Amazonian MPB as a sung poem that, although with common elements referred to the national canon of MPB, it has different aspects which are necessary to create another narrative about the same. Without belittling the narrative of invention of MPB, with an urban characteristic, according to Wisnik (2008), and initiated with Vinícius de Moraes and those who play Bossa Nova, referring to Tatit (2004), the sung Amazonian poetry studies show that it is necessary to be careful with homogenizations, since, for instance, the urban at Amazon is different from the southeast urban, existing an interpretation of the cited element with the forest. With regard to the rapprochement between music and poetry, without denying the importance of Vinícius de Moraes in the fifties, there is since the thirties the Waldemar Henrique's work with a poetic word, creating a sung poetic tradition which, initiated by the bandmaster, it passes through Ruy and Paulo André Barata, Walter Freitas, reaching the contemporaneity.
\end{abstract}

Keywords: Sung poetry. MPB. Amazon.

O objeto de análise deste trabalho se insere no campo do que será chamado de poesia cantada urbana brasileira, tendo como foco a MPB. Portanto,a reflexão que este estudo busca trazer, como forma de enriquecimento para o já conhecido debate, diz respeito a uma tradição que, embora com elementos comuns à grande narrativa de origem da poesia cantada urbana brasileira, apresenta seus diferenciais. Trata-se da poesia cantada urbana amazônica, em que o adjetivo "amazônica" dá ao qualificativo "urbana" conotações próprias, que se ligam à produção literária sobre a região.

Como já sugerido, no Brasil já existem grandes pesquisadores sobre o que se convencio-

\footnotetext{
1 Professor doutor pela Universidade federal do Sul e Sudeste do Pará. Doutorando pelo Programa de PósGraduação em Letras da UFPA. E-mail: josicleisouza@yahoo.com.br
} 
nou chamar de poesia cantada ou palavra cantada: Luiz Tatit, Zé Miguel Wisnik, dentre outros. Essa poesia cantada no Brasil se relacionaria, como será visto, com o termo guarda-chuva MPB, cuja narrativa se consagrou a partir de uma realidade eminentemente sudestina. Apesar da profundidade dos pesquisadores sobre o tema, é preciso observar que tais narrativas muitas vezes deixaram de lado outros contextos de produções poéticas cantadas no campo da MPB, como, por exemplo, o amazônico, correndo o risco de se homogeneizar processos que apresentam elementos diferenciais. Assim, essa poesia cantada produzida em Belém, espaço urbano amazônico, em que há o diálogo entre o urbano e o rural, traz a possibilidade de se perceber uma outra tradição da MPB.

\section{A MPB enquanto poesia cantada}

Como o objetivo deste trabalho tem como foco a poesia cantada, tendo como recorte a MPB na Amazônia, far-se-á uma definição mínima da relação entre poesia e MPB enquanto canção. O conceito elementar de canção é o de uma composição musical que contém um texto cantado, fenômeno comum a todos os povos. Mas quando neste trabalho se usa a expressão poesia cantada é para se delinear que o texto cantado possui uma preocupação literária em sua estrutura. Em sua definição de MPB, Wisnik apresenta tal característica como um elemento comum a esse universo musical brasileiro,

\footnotetext{
Originária da cultura popular não-letrada em seu substrato rural, desprende-se dela para entrar no mercado e na cidade; deixando-se penetrar pela poesia culta, não segue a lógica evolutiva da cultura literária, nem se filia a seus padrões de filtragem, obedecendo ao ritmo da permanente aparição/desaparição do mercado, por um lado, e ao da circularidade envolvente do canto, por outro; reproduzindo-se dentro do contexto da indústria cultural, tensiona muitas vezes as regras da estandardização e da redundância mercadológica. Em suma, não funciona dentro dos limites estritos de nenhum dos sistemas culturais existentes no Brasil, embora se deixe permear por eles (WISNIK, 2004, p. 123).
}

Apesar de não estar atrelada ao sistema literário, a MPB vai ter na preocupação poética com as letras um elemento identificador seu. Segundo o autor, o termo "popular", que acompanha a produção de canções no Brasil, a partir da bossa-nova teve uma bipartição em seu significado, de um lado passou a significar a música consumida pela maioria da população, com uma acentuação passional, que se convencionou chamar de "brega", e de outro, uma canção intelectualizada, com preocupações literárias, e de extrato universitário. (WISNIK, 2004, p. 121). A relação, no campo da canção, do termo "popular" com uma intelectualidade e com o meio universitário com gosto literário se dá pelo viés ideológico em que se propunha pedagogicamente uma arte popular-nacional. Assim, a MMPB (Moderna Música Popular Brasileira), depois reduzida para MPB (Música Popular Brasileira), teve em sua proposta inicial um engajamento de esquerda de viés nacionalista (TATIT, 2004, 82). Mas uma característica também dessa MPB, herdada da canção popular, segundo Tatit, é a oscilação entre o canto e a fala (TATIT, 2004, p. 43). Desse modo, essa palavra poética cantada vai ser uma marca da MPB.

A grande narrativa da MPB elegeu como marco zero dessa poesia cantada o encontro de Vinícius de Moraes com a Bossa Nova, significando tal evento a aproximação entre a Literatura e a Música. Inicialmente serão mostrados os problemas para que essas duas linguagens dialogassem no país, até a sua superação, quando da referida aproximação no contexto sudestino, e depois, apesar da repercussão em Belém desse processo inter-semiótico músico-poético a partir da bossa nova, far-se-á a abordagem dos elementos específicos que atuaram na criação dessa MPB no espaço urbano amazônico. 


\section{Literatura e Música no Brasil: origens das distâncias entre o erudi- to e o popular}

Hoje parece haver uma maior aceitabilidade da MPB enquanto possibilidade de poesia cantada. Talvez o maior exemplo de tal aceitação seja o fato de Chico Buarque recentemente ter recebido o prêmio Camões de Literatura, o maior ofertado para autores de Literatura de língua portuguesa. Mas, segundo Tatit (2004), houve uma demora em se consolidar a costura entre o verso e música no Brasil. Tal fato se deu devido ao distanciamento entre a intelectualidade ligada à Literatura e as camadas populares ligadas à canção, logo após a independência. Wisnik (2008) mostra que os motivos desse distanciamento remontam aos nossos tempos de colônia,

(...) a música e as artes plásticas, tidas como artesanais e mais próximas das funções puramente técnicas, são praticadas tendencialmente no Brasil, na tradição colonial, por negros e mulatos, enquanto as belas-letras, distantes do trabalho manual, são prerrogativa de brancos. (WISNIK, 2008, p. 54)

É possível, assim, perceber que a divisão social entre brancos de um lado, e africanos, afrodescendentes e indígenas de outro, se relaciona também à palavra escrita, ligada às elites, e à palavra cantada, ligada à oralidade popular. Para Tatit, até antes da bossa-nova, a produção poética ligada ao cânone literário esteve desvinculada da canção popular, entendida esta como a produção musical feita por pessoas não pertencentes ao meio musical erudito, e com letras que falavam do universo desses sujeitos, como o samba.Tal produção ganhou um alcance maior com o surgimento do disco e do rádio, saindo das rodas de samba e alcançando um grande público (TATIT, 2004, p. 33-35).

Segundo o pesquisador, o encontro entre a palavra poética e a música, que geraria a poesia cantada de que se está tratando, como já apontado, seria consolidado nos anos 50 quando Vinícius de Moraes se aproximou dos bossa-novistas, de onde teria derivado a chamada Música Popular Brasileira, MPB, (TATIT, 2004, 51). No entanto, se esse processo se consolidou no início da segunda metade do século XX, seu processo de construção começou na primeira metade daquele século. E é na história de como se deu tal processo de construçãoque este trabalho busca acrescentar outros elementos que não entraram na narrativa de invenção da MPB, mais precisamente os elementos especificamente amazônicos.

Em seu livro Pequena história da Música (1951), Mário de Andrade, no capítulo Música popular brasileira, se por um lado reconhecia a existência e o valor de uma produção de canções de caráter urbano, feita por não eruditos, citando Noel Rosa e Donga como exemplos vindos do samba (ANDRADE, 1987, p. 1820), ao mesmo tempo inseria tal produção em um campo de maior de abrangência, que era a música popular, sendo a mesma aquela feita pelas classes populares, como expressão de uma nascente nacionalidade, com destaque para o aspecto predominantemente rural em tal produção.

Segundo Wisnik (2006, 203-204), a canção popular, associada ao folclore, de caráter rural, defendida por Mário de Andrade e também Villa-Lobos, iria, com o tempo, perder terreno para a produção urbana, que geraria mais tarde a MPB. O exemplo urbano fundador dessa produção apontado por diferentes pesquisadores é o já referido samba, a partir do Rio de Janeiro. Este, por sua vez, teria sido modificado pela bossa-nova, tendo a poesia de Vinícius de Moraes sido inserida nessa produção. Pode dizer-se que essa foi a narrativa de invenção da tradição da MPB. Mas a sigla, como afirmado, somente viria após a bossa-nova, havendo uma dificuldade em demarcar o que definiria musicalmente tal produção,

O caráter híbrido, aberto, provisório da ideia de música popular brasileira (com minúsculas) explica, em parte, por que a MPB (com maiúsculas), mais do que um gênero específico, é um guarda-chuva de vários gêneros, movimentos e estilos tão diferenciados que, mal parafraseando Cecília Meireles, todo mundo sabe o que é, mas ninguém consegue explicar. A MPB, portanto, define-se mais como uma 
instituição sociocultural, depositária de uma tradição e de um conjunto de cânones estéticos e valores ideológicos (NAPOLITANO, 2007, p.6).

Napolitano afirma ser a MPB, portanto, um termo guarda-chuva para muitas e diversas produções no campo da canção após o período bossa-novista. Mas ao se cotejar as diferentes produções inseridas no termo guarda-chuva MPB, é possível afirmar-se que grande parte dessas canções, apesar de suas diferenças no que diz respeito ao campo musical, tem em comum o trabalho com a palavra poética, como já apontado por Wisnik. Mas se é consenso no meio acadêmicoa afirmação de que esse elemento é identificador para MPB, outra afirmação do pesquisador, a de que esta tem um caráter urbano, precisa ser modalizada quando o contexto se transfere do sudeste brasileiro para a Amazônia.

\section{Waldemar Henrique: o urbano e o rural amazônico, para além da dico- tomia}

Chega-se, então, ao ponto da reflexão em que a produção amazônica apresenta em parte uma diferenciação em relação ao que se construiu como narrativa de origem da MPB, pois, na capital paraense, o urbano e o rural não são termos tão dicotômicos assim, pelo contrário. Desse modo, a afirmação de Wisnik sobre a hegemonia do urbano sobre o rural na MPB não serviria totalmente como ferramenta para a leitura da história da mesma na Amazônia. Um pesquisador da canção amazônica que percebeu esse entrelaçamento entre o rural e o urbano na cidade de Belém foi Tony Leão da Costa,

De certa maneira, a cidade se desdobrava rumo aos rios, e as populações ribeirinhas, de cidades pequenas e médias. Assim, Belém era, e é até hoje, uma cidade estendida. Exercia influência nas vidas dos moradores de cidades do interior ou de ilhas que circulavam sua parte urbanizada. (...) pode-se também pensar no campo estendido rumo à cidade - é uma via de mão dupla, portanto (COSTA, 2013, p. 68).

Sendo Belém uma cidade estendida, assim como elementos do urbano eram levados para o meio rural, também muitos elementos do meio rural eram levados para a cidade. Nesse sentido, o popular que está na origem da poesia cantada na MPB na Amazônia não se liga somente ao espaço urbano. Esse popular se liga à produção cultural dos grupos subalternizados do meio rural interligados à cidade. No caso da Amazônia esses grupos subalternizados do meio rural acabam por se estender para as periferias de Belém, desenvolvendo manifestações como o boi-bumbá e o carimbó, que são aproveitadas pelos compositores de MPB da região.

Outro elemento diferencial dessa MPB amazônica, além da aproximação entre o urbano e o rural, é que a mesma tem outra narrativa de origem, anterior à bossa-nova, surgida com um compositor da região, mas com renome nacional e até internacional. Trata-se de Waldemar Henrique (1905-1995), que pode ser considerado como o marco zero dessa MPB amazônica.

Waldemar Henrique, compositor da primeira metade do século XX, foi o primeiro paraense a se inserir nesse mercado cultural da canção brasileira, que se desenvolveu com os incrementos tecnológicos, como o rádio e o disco de vinil. Waldemar Henrique se associa ao projeto mariodeandradino de canção brasileira, sendo apontado pelo poeta, músico e pesquisador paulista como um dos grandes nomes da música brasileira.

O compositor paraense teve um contato íntimo com a Literatura, seja de origem escrita, seja de origem oral popular. Foi o primeiro músico com formação erudita da Amazônia a projetar o universo amazônico em nível nacional e internacional. Waldemar Henrique, em sua série de canções amazônicas, transpôs para a canção o universo mítico, o cotidiano do caboclo com íntimo contato com a natureza. Nessa atitude, ele se aproximava dos modernistas do restante do país e acompanhava os esforços dos modernistas paraenses de afirmação de uma arte baseada em uma afirmação identitária amazônica, como Bruno de Menezes, em que a antiga barreira entre a cultu-

https://periodicos.unifap.br/index.php/letras

Macapá, v. 9, n. 2, $2^{\circ}$ sem., 2019 
ra consumida por um público mais letrado e a cultura produzida pelo povo é quebrada, ou ao menos sofre sua primeira grande fissura.

Sua música é muito diversa, havendo, por exemplo, séries ligadas aos mitos amazônicos e aos ritos afro-brasileiros. Para este trabalho interessa o primeiro exemplo. Com relação a essa série, além da pesquisa folclórica, seu trabalho está assentado na tradição das narrativas e da poesia oral da região, o que exigia uma grande teatralidade das intérpretes de suas canções, como forma de recuperar os elementos performáticos que compõem estas narrativas e estes poemas. É o próprio compositor quem afirma,

A intérprete que eu considero ideal para as minhas músicas é a intérprete que põe seu primeiro cuidado na interpretação do texto; seria uma declamadora que cantasse, porque a cantora lírica habituada a cantar textos para os quais dá pouca importância (...) não se apercebeu do texto que ela cantou.(...) A cantora ideal é aquela que esquece tudo e pensa no texto (apud PEREIRA, p. 119).

Apesar de Waldemar Henrique compor para o canto lírico, percebe-se já nele a preocupação com a narrativa oral, comum à fala, se aproximando a intérprete henriqueana daquilo que Zumthor chamou de performance (ZUMTHOR, 2010, p. 31), com o objetivo de buscar recuperar algo do que Benjamin chamou de arte de narrar (BENJAMIN, 1983, p.57). Desse modo, o projeto do compositor amazônida vai ao encontro daquilo que Luiz Tatit afirma ser uma das marcas da canção brasileira, que é a aproximação com a fala (TATIT, p. 43).

Um pequeno relato poderia mostrar o grau do êxito de Waldemar Henrique em se aproximar dessa narrativa oral popular. A sua canção Uirapuru foi gravada por Zizi Possi no álbum Valsa Brasileira, de 1993, e, ao ser questionada em uma entrevista concedida a Jô Soares naquele mesmo ano, sobre a autoria da composição, a intérprete afirmou não ter conhecimento, mas que a ouvia desde os seis anos, aproximando-a do domínio público. Não por acaso, apesar de executado por cantores líricos e orquestras em diferentes cidades do Brasil e do exterior, hoje as canções de Waldemar Henrique são cantadas também por muitos grupos de tradições folclóricas e intérpretes da MPB.

O referido compositor foi um dos precursores no Brasil da aproximação entre música e poesia, pois o mesmo, apesar de ter muitas composições próprias, também se esmerava em musicar poemas de poetas modernistas, como $O$ trem das Alagoas, de Ascenço Ferreira (FERREIRA, 1981), Chorinho, de Bruno de Menezes (MENEZES, 1984), Essa Nega Fulô, de Jorge de Lima (LIMA, 1928), além de textos do poeta Antônio Tavernard, dentre outros, tendo sempre como elemento comum a oralidade poética popular.

Podemos então dizer que no Pará o gesto de aproximação entre música e poesia de repercussão nacional e internacional se deu por uma busca conjunta de cantar o universo amazônico, com base na cultura das camadas populares, em que o rural, entendido como o imaginário do homem do meio rural amazônico, não é posto de lado, ao contrário. Veja-se o exemplo da canção Foi Boto Sinhá, com letra do poeta Antônio Tavernard, recentemente gravada pela cantora de MPB Mônica Salmaso,

Foi boto, sinhá

(Antônio Tavernard/Waldemar Henrique)

Tajá-Panema chorou no terreiro

e a virgem morena fugiu no costeiro.

Foi boto, Sinhá.

Foi boto, Sinhô!

Que veio tentá e a moça levou

No tar dansará, aquele doutô,

Foi boto, Sinhá. Foi boto, Sinhô! 
Tajá-Panema se pôs a chorá.

Quem tem filha moça é bom vigiá!

O boto não dorme no fundo do rio, seu dom é enorme

quem quer que o viu.

Que diga, que informe se lhe resistiu,

o boto não dorme no fundo do rio... ${ }^{2}$

Tavernard, apesar de ser um poeta de uma linguagem mais erudita, compôs várias letras para série amazônica de Waldemar Henrique, a pedido do compositor, tendo sempre como características um eu enunciativo popular, marcado pelo imaginário mítico amazônico, imaginário este que desde o século XIX autores paraenses ligados ao cânone literário brasileiro já haviam divulgado nacionalmente, como Inglês de Sousa e José Veríssimo. A forte influência de Waldemar Henrique sobre os compositores da capital paraense, em que se destacam o imaginário mítico e elementos do ambiente interiorano, fez surgir um outro tipo de MPB, não exclusivamente urbano.

O país teria notícias de reverberações do projeto de Waldemar Henrique mais tarde, quando a MPB já estaria consolidada, na década de 70, a partir de um trio que consolidou o que se poderia chamar de MPB amazônica: o letrista e poeta Ruy Barata, o músico e filho do letrista, Paulo André Barata, e a intérprete Fafá de Belém.

\section{A consolidação da MPB amazônica: Paulo André, Ruy Barata}

A MPB, segundo Napolitano, vai ter na década de 70 o momento de consolidação. E Belém teve, embora de maneira mais tímida, um cenário que aqui consolidou um circuito de MPB. Mas, apesar de sofrer a influência sudestina, havia no cenário belemense um diferencial interessante, como bem mostra Tony Leão da Costa. Essa diferença foi a tentativa de "definir uma cara regional para essa sua criação". Essa "cara" estava ligada a uma construção identitária que passava por uma representação identificada com o chamado rural, que no Pará chamamos de "interior" (COSTA, 2008, p. 26). Merece destaque para os interesses deste trabalho a afirmação do historiador de que um mentor dessa geração foi Ruy Barata, poeta e intelectual expoente à época, também letrista das canções mais famosas feitas por seu filho Paulo André, e divulgada nacionalmente na década de 70 por meio da intérprete Fafá de Belém, que cantava as composições do poeta e de seu filho músico.

Pai e filho escreveram ou tocaram um capítulo importante da MPB amazônica, pois compuseram mergulhando suas letras nos mitos, como outrora fizera o maestro, mas também no cotidiano do trabalho, na relação do homem com a natureza, no cotidiano do homem comum da Amazônia, e na denúncia da exploração e destruição da região. Embora compusesse suas letras seguindo a linha de aproximação da fala com o canto, comum à MPB, Ruy Barata tinha consciência das limitações do texto poético na música,

A letra me põe numa grade. A poesia me dá liberdade. A letra tem que estabelecer comunicação com o público. A poesia não tem obrigações. A poesia transcende a palavra. A letra se mantém no plano temporal. Às vezes uma letra é poética, mas não obrigatoriamente (OLIVEIRA, 1984, p. 42).

A consciência dos limites da palavra na canção não impediu Ruy Barata de aprofundar poeticamente na Amazônia a experiência de diálogo entre palavra e música iniciada por Waldemar Henrique, compositor conhecido por pelo poeta, o que pode ser comprovado pela inserção de Fafá de Belém no cenário nacional da MPB, marcada pela valorização do texto poético.

No campo musical, pai e filho construíram uma releitura poética do carimbó, mas mos-

2 Disponível em https://www.youtube.com/watch?v=A0G3u3u_y0Y, acessado em 26 mai. 2019.

https://periodicos.unifap.br/index.php/letras

Macapá, v. 9, n. 2, $2^{\circ}$ sem., 2019 
traram também que a Amazônia não é só um imenso vale encharcado, havendo também uma Amazônia atlântica em contato com territórios para além do Brasil, interagindo e incorporando essas interações à cultura local, como a música caribenha que vinha pelas ondas dos rádios, que por sua vez não conseguiam sintonizar as emissoras do sul, e pelas trocas entre os barqueiros paraenses e os de outras localidades do Caribe. A aproximação entre essa identificação caribenha e a poesia cantada, esboçada pela parceria entre Paulo André e Ruy Barata seria, na passagem do século XX para o XXI, aprofundada pela banda Cravo Carbono, como mais adiante será visto.

Pai e filho também dialogaram com o bolero, negado pela Bossa Nova, em nome de uma expressão emocional mais comedida. Esse diálogo está presente na canção Foi Assim, que ficou nacionalmente conhecida na voz de Fafá de Belém. Segundo Luiz Tatit, o bolero se incluiria naquilo que se chamaria de brega, enquanto inflexão passional na melodia e na letra da canção (TATIT, 2004, p. 64). No entanto, o conhecimento musical atravessado pela Bossa Nova de Paulo André e o trabalho com a letra de Ruy Barata conseguiram imprimir ao estilo um refinamento, deixando a dramaticidade a cargo da performance de Fafá de Belém, que, se por um lado seguia a linha de outras cantoras da MPB, como Elis Regina, que aproximavam canto e fala, por outro recuperava o elemento interpretativo do texto proposto por Waldemar Henrique. Não por acaso o título do primeiro álbum da intérprete, de 1976, é Tamba-Tajá, nome de uma composição de Waldemar Henrique presente no referido álbum.

Uma composição que merece destaque no primeiro álbum de Paulo André Barata, Nativo, de 1978, homônima ao título do álbum, foi retirada do grande poema O Nativo de Câncer, de autoria de seu pai. Ruy Barata pretendia escrever um grande poema de dez cantos, mas que acabou ficando com somente dois por conta do seu falecimento. O destaque é merecido por dois aspectos: o primeiro é fato de não se tratar, como na maioria das vezes, de uma letra feita pelo pai para uma melodia do filho, e sim um arranjo de Paulo André para um trecho do poema de Ruy Barata; o segundo motivo é que, mesmo abordando o tema do amor, comum tanto à canção como ao poema, o texto traz uma profundidade comum à poesia escrita, mas não tanto à poesia cantada, pelo fato de ser uma abordagem ontológica do amor, chegando a quebrar com o uso convencional da língua. Por sua vez, essa abordagem ontológica da dor amorosa pela ausência do ser amado recupera um elemento comum às narrativas ficcionais e não ficcionais sobre o espaço amazônico, que são as grandes distâncias, presentes, por exemplo, em Euclides da Cunha, Ferreira de Castro e José Veríssimo. A referida canção chegou a ser tema de novela de rede nacional ${ }^{3}$.

\author{
Nativo \\ (Paulo André Barata/ Ruy Barata) \\ Desses rastros dormindo nasce um campo, \\ na reponta dos ventos e mugidos, \\ cavianas de cornos bubuiando, \\ barcarenas a ser, ou for, em sido \\ Há sempre o que sortir nesses doendo \\ de lonjura cilendo e sipurgando, \\ amor é meses-mares ciregendo, \\ amor é sipartindo e cichegando. \\ Amor é amar, em dois, predicativo, \\ amor é sisofrendo e cisofrido, \\ amor é simorrendo e cimatando \\ amor é dez em dois de simorrido \\ E tudo amor, amor, de erre aspado, \\ amor em solsolvido e solsoldado
}

3 A composição Nativo, mais Pacará e Indauê-Tupã fizeram parte da novela Aritana, da TV Tupi, em 1979. 
Paulo André Barata iria ainda lançar um segundo álbum, Amazon River, de 1980, consolidando assim o que neste trabalho se vem chamando de MPB amazônica, em que, sem excluir o aspecto urbano, o ambiente rural amazônico é traduzido poeticamente em canções.

O terceiro marco da MPB amazônica seria a obra de Walter Freitas, cujo trabalho não teve grande notoriedade no circuito nacional da $\mathrm{MPB}$, mas que pela radicalidade experimental tanto poética como musical e intenso diálogo com a Literatura, criou umaobra de grande importância para o que se vem chamando neste estudo de MPB amazônica.

\section{Walter Freitas: a radicalidade experimental e o diálogo com a Literatura}

A pergunta que o poeta Edson Coelho faz acerca da obra de Walter Freitas mostra um pouco a dimensão inventiva do processo criativo do compositor:

Quem conhece a obra de Walter Freitas? A resposta é certamente uma das mais injustas na arte contemporânea brasileira. Entretanto, basta Tuyabaé cuaá, seu único CD lançado, para incluí-lo entre os mais radicais -senão o mais radical- de nossos compositores-poetas (FREITAS, 2003, p. 09).

Walter Freitas, além de compositor, é ator, dramaturgo e romancista, tendo em 1981 adaptado para o teatro o livro Marajó (1947), segundo de Dalcídio Jurandir, que exerceu uma grande influência na obra cantada do músico. Em 1988 Walter Freitas lançou pelo selo Outros Brasis o álbum Tuyabaé Cuaá. Sua temática recorrente é a realidade e o imaginário mítico amazônico, mas também a cultura popular e os seus conflitos e lutas na região, observando a diversidade de sua conformação, tendo o texto poético uma densidade aliada a uma reinvenção do falar do sujeito amazônico. O prefácio de Edson Coelho para um dos livros de Walter Freitas confirma esse universo temático e essa reinvenção da língua,

Seus personagens são o povo, suas situações são as vividas pelo povo, seus heróis são do povo, na travessia nomeada como "história oculta". Estilisticamente (considerando a parte literária), este repertório gerado no povo incorpora palavras índias e negras, num estilo que chega a ser "estranho" à música brasileira (FREITAS, 2003, p. 09).

A estranheza apontada por Edson Coelho no estilo de Walter Freitas está em um elemento que vai de encontro àquilo que seria, segundo Tatit, a marca da canção brasileira, o canto aproximado da fala. Walter Freitas faz opção por uma ruptura, pois o canto de sua canções é muitas vezes difícil, devido à utilização de extensões vocais para além do falar cotidiano, além de a linguagem recriar e adensar poeticamente o falar amazônico, num gesto poético semelhante ao de Guimarães Rosa.

Como parceiros em algumas letras das canções do álbum temos Antônio Moura e João Gomes, dois grandes nomes da poesia contemporânea, sendo o último parceiro de compositores de renome nacional, como Dante Ozzetti e Zeca Baleiro. Mas mesmo havendo parceiros em suas composições, semelhante ao que acontecia nas parcerias entre Waldemar Henrique e Antônio Tavernard, era respeitada no processo criativo a poética proposta por Walter Freitas. Assim, mesmo retomando a força do elemento mítico, o que o aproxima de Waldemar Henrique no campo temático, e buscando um aprofundamento poético, como fez Rui Barata, o criador estabelece uma ruptura musical, ao não se aproximar da estilização de ritmos populares, como fizeram autores da MPB, incluindo Paulo André Barata, e ao não fazer um canto próximo da fala, ao pon-

${ }^{4}$ Disponível em https://www.youtube.com/watch?v=5RTWyrDK8Oo, acessado em 26 mai. 2019. 
to de uma completa fruição da obra demandar muitas vezes uma consulta às letras e explicações de rodapé presentes no encarte do álbum.

A obra de Walter Freitas é fruto de uma profunda pesquisa de campo, seja no campo da música, como no campo da história, da oralidade e da cultura dos diversos povos da Amazônia, o que o coloca entre outros artistas-pesquisadores da região, como

Bruno de Menezes e Dalcídio Jurandir, no campo literário, e o já citado Waldemar Henrique, no campo musical. Mas a ligação com a obra dos dois escritores paraenses supracitados aparece também pela incorporação de passagens das obras dos referidos autores às composições do álbum.

No que diz respeito a Dalcídio Jurandir, Walter Freitas faz referência ou chega mesmo a colocar passagens dos romances dalcidianos em suas letras, como é o caso do romance Três casas e um rio (1958), em que foi possível perceber a referência a duas imagens: a primeira é "pixuneira em flor" (JURANDIR, 1994, p. 220), presente na canção Salvaterra, e "A maria-é-dia bateu as asas na telha, piando-lhes: já é dia, já é dia" (JURANDIR, 1994, p. 87), presente na canção Janataîra, adaptada no verso "já é dia Maria já é”. Na mesma canção tem-se a passagem "não, mãe do rio, não vai embora com as tuas águas, com as tuas águas", que foi extraída do romance Ponte do Galo (1971) (JURANDIR, 2017, p. 56). Do mesmo romance tem-se a passagem "mas se asserene se asserene" (JURANDIR, 2017, p. 71), presente na canção Fruta Rachada. O próprio título desta canção, enquanto referência erótica à mulher está presente no romance Marajó (JURANDIR, 2008, p. 36). Do mesmo romance temos a expressão "um índio no remo" colocada na já referida canção Salvaterra, que é o nome de um município marajoara. Ainda com relação a Dalcídio Jurandir, tem-se na canção Igaçaba, em parceria com João Gomes, mais uma vez referências ao romance Marajó, de 1947, que, como já referido, foi adaptado para o teatro por Walter Freitas,

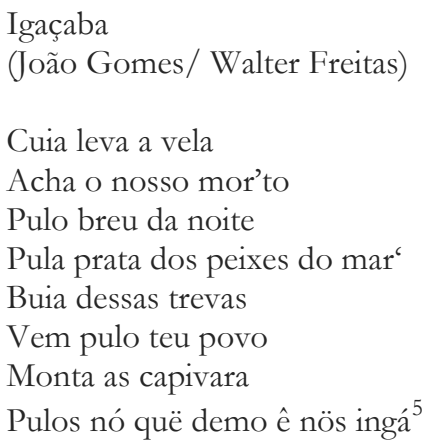

Igaçaba remete a um tipo antigo de urna funerária indígena, o que não aparece na canção. Mas quando se associa o termo ao apelido dado a uma personagem do segundo romance de Dalcídio Jurandir, o título e a introdução se tornam mais claros ao receptor, já que Igaçaba, em Marajó, é um vaqueiro que cai no rio durante o embarque de gado, sendo comido por piranhas, não sendo encontrado de imediato. A introdução da letra da canção faz referência ao ritual para que se encontre o corpo do afogado, presente na seguinte passagem do romance,

- Procurem ele. Ele não aparece, gente. Por amor de Deus! [...] Então com as caras suadas e queimadas, silenciosos e espantados, os vaqueiros se dirigiram para o carananzal. [...] Atiram tarrafas, espetam vara no leito do rio, lançam a linha dos anzóis, apalpam todo o fundo. As velhas aconselharam a vela de cera dentro de uma cuia que flutuou no rio. Onde parasse, ali estava o corpo do afogado (JURANDIR, 2008, p. 328).

Outra referência literária modernista amazônica no álbum de Walter Freitas é a canção Oração da Cabra Preta, homônima ao título de um poema publicado pelo poeta Bruno de Menezes

${ }^{5}$ Disponível em https://www.youtube.com/watch?v=pHIrkLElrR8, acessado em 26 mai. 2019.

https://periodicos.unifap.br/index.php/letras

Macapá, v. 9, n. 2, $2^{\circ}$ sem., 2019 
em 1939, no livro Batuque, primeira obra poética afro-brasileira. Bruno de Menezes fez o trabalho de colagem da oração praticada por mestre Desidério, pajé ou pai de santo que viveu em Belém no início do século XX, colocando-a em seu poema. Walter Freitas, por sua vez, musicou a referida oração, que possui um registro muito semelhante feito por Mário de Andrade, inserido no livro deste pesquisador que trata de músicas de feitiçaria (ANDRADE, 1963, p. 124-123).

Vê-se, portanto, que, apesar da experimentação estética que estabelece uma ruptura com o que se entendia até então como MPB, enquanto poesia cantada, há um estreito diálogo entre a Literatura modernista amazônica e o trabalho de Walter Freitas, em um processo de atualização da tradição poética cantada.

\section{Cravo Carbono: a palavra entre a dança e o denso poético}

A banda Cravo carbono lançou o álbum Peixe Vivo em 2001. De um modo experimental, fez um diálogo com diferentes sonoridades da região, como o carimbó, o boi-bumbá e a guitarrada, gerando assim um trabalho que, na tradição da poesia cantada amazônica, havia sido esboçado por Ruy e Paulo André Barata, em que o apelo somático musical vinha juntamente com um texto poético. No entanto, em termos de letras, o letrista Lázaro Magalhães ousa arriscar o processo comunicativo que Ruy Barata dizia ser comum à letra da canção, em nome de um adensamento poético que, com ritmos de apelo dançante criam um efeito singular. Ou seja, se tem uma música que propõe a dança, ao mesmo tempo em que há uma letra que, apesar de acompanhar por meio da performance do canto e às vezes até tematicamente a construção musical, propõe a fruição poética. Um exemplo do que se está afirmando é a composição Mercúrio, a partir de um ritmo conhecido na região como brega. A música tem um apelo dançante, mas a letra, apesar de em diálogo com a música por estilizar um ritmo ouvido nos garimpos amazônicos, demanda um tempo maior de fruição, demandando do receptor também uma audição reflexiva,

Mercúrio

Cravo Carbono

Solto o paralelo

Amarelo

Me desmancha a tolerância

Desafio de Amor

É azul distância

Ar erguido

Ante a lembrança

$\mathrm{O}$ peixes esquecem

Os peixes são felizes

Os peixes engolem

Água, abandono

Eu vou nadar

Até a Superfície

O seu avesso é cortês

Soube de tudo mais de uma vez

Eu vou correr, eu vou beber,

Eu vou cair, eu vou sumir

Até você fugir de mim

Até você... render os cães

No meu quintal

Mentir a noite inteira

Para o fogo, a água e o sal

Mas minha dor é oriental

E agora é... livrar a jóia do metal

Livrar a jóia do... 


\section{A minha dor é oriental \\ De mina mata aqui o mal \\ Tomei a correnteza até o mar \\ E agora é... livrar a jóia do metal ${ }^{6}$}

Assim, a proposta da banda acabou por aproximar o que seria a canção para se dançar, principalmente por meio da pesquisa sobre guitarrada levada a cabo por Pio Lobato, da canção para se fruir pela construção poética.O trabalho de Lázaro Magalhães como letristana banda Cravo Carbono se inscreve na tradição da poesia cantada urbana amazônica, trazendo em muitos momentos experimentações poéticas em jogos e sonoros e de imagens que trazem para sua poética um hermetismo, assim como Walter Freitas, mas recuperando uma aproximação com a fala. Infelizmente, após a experiência do Cravo Carbono, outros grupos e artistas seguiram na esteira que deu visibilidade ao modo paraense de se tocar guitarra, trazendo inclusive à cena nacional os chamados Mestres da guitarrada, com destaque para Vieira, mas sem a preocupação do denso trabalho poético de Lázaro Magalhães.

O que começaria inicialmente como uma pesquisa sobre as possibilidades da guitarra, como é possível perceber no título de um dos instrumentais do álbum Peixe Vivo, Recado para Lúcio Maia, acabou por ir se diluindo no cenário local. Também começou a ganhar destaque no cenário nacional o tecno-brega, também experimentado no segundo álbum da referida banda, com uma letra construtivista de Lázaro Magalhães, Café Br. Infelizmente, tanto a guitarrada quanto o tecno-brega se limitaram a ser "música de festa", em que a construção poética da letra não tem obrigação de ser poética, como afirmava Ruy Barata, ficando a experiência poética de Lázaro Magalhães aparentemente sem continuidade no campo de uma música mais somática.

\section{A tradição da poesia cantada hoje}

A música de festa ou música dançante prescinde daquilo que é um elemento fundamental na tradição da MPB, o diálogo entre Literatura e Música, o trabalho poético com a palavra. Diante da grande visibilidade da música dita paraense de festa em nível local e nacional, a longa tradição da poesia cantada na cidade, que teve grande visibilidade no cenário musical de oitenta e setenta parecia estar desaparecendo. Mas ante essa falsa impressão vale a pena ler o alerta do compositor Henry Burnett, que possui uma grande produção no campo da poesia cantada da MPB,

O que está na superfície não representa o todo do que se faz e do que existe, isto é, Paulo André e Ruy
Barata tem seguidores, sua música não está sepultada na proscrição da incapacidade de ouvir
plenamente. Obras inteiras podem se desenvolver sob este manto da obscuridade e, ainda assim,
pertencerem ao mundo, ao que existe, à criação. Claro que no mundo da hiperexposição é cada vez
mais difícil acreditar em algo que não se vê, e no nosso caso, que não se ouve. É quase uma crença
mítica. Permitam-me garantir que essas obras existem, e nem sempre a história sobre a qual elas se
assentam as torna menos importantes, ainda que sobre elas pese certo anacronismo (BURNETT, 2013,
p. 83).

A comprovação da continuidade da tradição da poesia cantada, apesar agora de estar longe dos holofotes, foi possível de ser percebida em um evento de compositores na extinta Casa Carta, no centro de Belém, em que houve um encontro quando diferentes criadores mostraram suas mais recentes criações. Nesse encontro foi possível perceber diversos criadores que seguem a tradição de unir composição poética à música. Dentre os participantes desse encontro, um que reivindica para si a herança dessa poesia urbana amazônica, buscando atualizá-la é Mateus Moura, cuja composição Matinta Chegou, em parceria com Luana Moura e João Pedro Moura, parece dialogar com Matinta Perera, de Waldemar Henrique, mas no sentido de uma réplica, em

${ }^{6}$ Disponível em https://www.youtube.com/watch?v=XDHFlnbpFGQ, acessado em 26 mai. 2019. 
que a mudança do lugar de enunciação, que não é mais o do homem falando sobre a mulher, nos apresenta a própria Matinta, em um canto dramático, ao modo do maestro, mas agora visceralmente, e ganhando voz própria, numa identificação de ancestralidade que desconstrói a visão negativa sobre as mulheres que são apontadas como matintas.

Matinta chegou
(Mateus Moura/Luana Moura/João Pedro Moura)

Matinta chegou

Vim do fundo do olho d'água

que murmura na floresta

eu vim da boca da noite

pela estrada que ninguém trilhou

sou a bruxa preta velha

mãe da avó do teu avô

Abre a roda

ronca a onça

rebate o tambor

Matinta chegou

Vim de dentro com o vento

assobiando num encante

vim das sombras, vim da luz

vim de todas as falanges

sou a ave, sou a cobra

sou a folha, o diamante

Abre a roda

ronca a onça

rebate o tambor

Matinta chegou

Já te disse seu caboco

eu sou a filha da floresta

minha mãe é quem decide

o que fica e a que presta

se nós fumo nesse fogo

nesse fogo eu te trago

Abre a roda ronca

a onça rebate

o tambor

Matinta Eu sou

Matinta Eu sou

Matinta Aqui estou ${ }^{7}$

Nessa canção de Mateus Moura, elementos comuns à experimentação moderna da canção brasileira, como a aproximação entre instrumentos tradicionais, como o curimbó e o banjo, se juntam à instrumentação comum à musica pop, como a guitarra e o baixo, elementos presentes na MPB desde o Tropicalismo. Em termos de letra, percebe-se a atualização da MPB amazônica por meio da incorporação no texto poético dos debates identitários de emponderamento de minorias, como é o caso das mulheres, inserindo-se o elemento feminino no espaço do carimbó, até então tido como um território masculino.

O trabalho de Mateus Moura foi inserido para comprovar aquilo que foi apontado por

\footnotetext{
${ }^{7}$ Disponível em: https://www.youtube.com/watch?v=aP0HA-9HoyM Acesso em: 08 mai. 2019.
} 
Burnett, o fato de que, apesar de essa produção poética cantada não estar atualmente nos holofotes, ela ainda tem muitos criadores que buscam a atualização dessa tradição. Muitos criadores de grande valor poético poderiam ser citados, como o próprio Henri Burnett, mas sob o risco de cometer injustiças, e pela limitação que o gênero artigo impõe, neste trabalho houve a delimitação aos cinco exemplos supracitados, mas que servem

para mostrar haver uma certa $\mathrm{MPB}$, que, mesmo com elementos comuns à MPB consagrada no sudeste, no que diz respeito à preocupação literária, possui uma poética própria em que o urbano e o rural dialogam, vindo esta tradição de antes da Bossa Nova. Assim, este trabalho pretende mostrar que na Amazônia a canção e a Literatura estabeleceram um diálogo com características próprias.

\section{Referências}

ANDRADE, Mário de. Pequena História da Música. BH: Itatiaia, 1987.

BENJAMIN, Walter. O narrador. In BENJAMIN, Walter et al. Textos escolhidos, 2. ed. São Paulo: Ed. Abril Cultural, 1983 (Coleção Os Pensadores).

BURNETT, Henry. Belém: música e identidade na cidade plural. Artefilosofia, Ouro Preto, n.14, p. 7283, jul. 2013.

COSTA, Tony Leão da. Música do Norte: intelectuais, artistas populares, tradição e modernidade na formação da "MPB" no Pará (anos 1960-1970). Dissertação (Mestrado em História) Faculdade de História, Universidade Federal do Pará, Belém, 2008.

FREITAS, Walter. Dez̧Memórias: pelos 10 anos da morte de Chico Mendes. Belém: IAP, 2003.

HENRIQUE, Waldemar. Waldemar Henrique, canções. Belém: Secretaria de Estado de Educação, Fundação Carlos Gomes, 1996.

JURANDIR, Dalcídio. Marajó. 4. ed. edição. Belém: EDUFPA; Rio de Janeiro: Casa Rui Barbosa. 2008.

. Três casas e um rio. 3. Ed. Belém: CEJUP, 1994.

. Primeira Manhã. Belém: Marques Editora, 2016.

. Ponte do Galo. São Paulo: Martins; Rio de Janeiro: INL, 1971.

MENEZES, Bruno de. Batuque. 2. ed. Belém: Oficinas Pará Ilustrado, 1939.

NAPOLITANO, Marcos. A síncope das idéias: a questão da tradição na música popular brasileira. São Paulo: editora Fundação Perseu, 2007.

OLIVEIRA, Alfredo. Paranatinga. Belém: Secretaria de Estado de Cultura, Desportos e Turismo, 1984.

PEREIRA, João Carlos. Encontro com Waldemar Henrique. Falangola: Belém, 1984.

SALLES, Vicente. Música e músicos do Pará. 2.ed.Belém: Secult/Seduc/Amu-PA, 2007.

SOUSA, Inglês de. Contos amazônicos. São Paulo: Martin Claret, 2005.

TATIT, Luiz. O século da canção. Cotia: Ateliê Editorial, 2004.

WISNIK, José Miguel. Um intelectual nativo. In. NEVES, Santuza Cambraia, COELHO, Frederico Oliveira; BACAL, Tatiana Org. A MPB em discussão, entrevista. Belo Horizonte: Editora UFMG, 2006, p.197-220.

. Machado Maxixe: o caso Pestana. São Paulo: Publifolha, 2008.

- Algumas questões de música e politica no Brasil. In: Cultura brasileira : temas e situações. São Pau-

lo: Ática, 2004.

VERÍSSIMO, José. Cenas da vida amazônica. 4. ed. Belém - PA: Estudos Amazônicos, 2013.

ZUMTHOR, Paul. Introdução à poesia oral. Trad. Jerusa Pires Ferreira, Maria Lúcia Diniz Pochat, Maria Inez de Almeida. Belo Horizonte: Editora UFMG, 2010.

Envio: $30 / 08$

Aceite: $08 / 11$

https://periodicos.unifap.br/index.php/letras

Macapá, v. 9, n. 2, $2^{\circ}$ sem., 2019 